ワークショップ I -1

BCL6転座の遺伝子構造とリンパ腫の病態

赤坂尚司, 大野仁嗣, 内山卓

京都大学医学部第一内科

$\mathrm{B}$ 細胞リンパ腫(B-NHL)では、多彩な染色体 転座が認められ、病理組織型や臨床経過との密 接な関連が報告されてきた。BCL6遺伝子を責任 遺伝子とする $3 \mathrm{q} 27$ 転座（BCL 6転座）は、 follicular lymphoma (FL)の6.4-14.3\%, diffuse large B-cell lymphoma (DLCL)の 28.6-35.5\%に認められるが、免疫グロプリン遺 伝子(IG)だけでなく多様な染色体領域を転座の パートナーとすることを特徽としている。我々 は、多数の臨床材料から抽出したDNAをテンプ レートとし、独自に開発したlong-distance (inverse) PCRを用いてBCL6転座接合部をク ローニングしてきた。今回は、これらの遺伝子 レベルでの解析結果と、B-NHLの臨床像との関 連を報告する。（結果）サザン法でB-NHLの58 例にBCL6の再構成が認められた。病理診断は、

FL 15例、DLCL 40例、 small lymphocytic lymphoma ¿small noncleaved lymphoma各1 例、未䛦断1例。転座のパートナーは、30例が IG、23例はnon-IG で、既知の遺伝子は、H4 histone (6p21.3) 5例、TTF (4p13)、 heat shock protein (14q32, 6p12)、TFRC (3q29) 各 2例、PIM-1 (6p21)、NAC (12q23-q24.1)、 CIITA (16p13) 各1例であった。末知の領域は7 ヶ所で、4例が3q26-q27の共通領域にマップさ れた。残りの5例はBCL6内のdeletionまたは point mutationであった。2例では2つの独立し たBCL6転座が認められた。他の遺伝子再構成と の関連をみると、12例でC-MYCまたはBCL2の 再構成も認められた。臨床経過を検討したとこ ろ、203例のDLCLのうち、BCL6再構成陽性症 例 $(n=43)$ は陰性症例 $(n=160)$ に比し、予後不良 ( $\mathrm{p}=0.041)$ であった。さらにDLCLのBCL6転座陽 性症例をIGとnon-IGパートナーに分けてで比較 したところ、non-IG群は予後不良 $(\mathrm{p}=0.044)$ で あった。(考察) Bcl-6蛋白はBCL 6転座の有無 に関わりなく多くのB-NHLに発現しているの で、BCL6転座とB-NHLの腫場発生との関連は 不明のままである。我々はBCL6転座の多彩な パートナー遗伝子を明らかにし、転座による BCL6の発現異常は量的な変化では説明できない ことを示唆した。今回の解析によって、BCL6転 座の多様なパートナーが予後や臨床像に影響を 与えることが明らかになったことから、BCL6転 座はB-NHLの腫演発生に重要な役割を果たして いることが示唆された。
ワークショップ I-2

B細胞性リンパ腫原因遺伝子BCL6と結合す る白血病原因遺伝子Evi9

中村 卓郎、斎木 由利子、山崎ゆかり

癌研究所発がん研究部

Evi9遺伝子は、BXH2マウス白血病のレトロウィ ルス挿入部位から同定された新しい発がん遺伝子 である。Evi9はC $2 \mathrm{H} 2 \mathrm{Zn}$ フインガー蛋白をコード

し、3種類のisoformが存在する。BXH2骨髄性白血 病細胞においてレトロウィルスの挿入によりEvi9 の発現が六進すること、Evi9をNIH 3T3細胞に導 入するとトランスフォーム活性を示すことから、 Evi9はドミナントオンコジーンであると考えられ た。Evi9蛋白の3種類のisoformの細胞内局在学調 ベると、 double Znフィンガーを有するものは核内 に限局し、逆にdouble $\mathrm{Zn}$ フィンガーのないisoform は細胞質に存在することがわかった。核内に存在 するEvi9は、特徵的なドットパターンを示した。 この局在様式を手掛かりとしてEvi9と結合する蛋 白を検討すると、Evi9はBCL6とこの核内構造物に 共存することがわかった。免疫沈降法にてBXH2 白血病細胞とRaji細胞においてEvi9とBCL6は共沈 する。さらに、両者はEvi9のdouble Znフィンガ ーとBCL6のPOZドメインを介して直接結合するこ とが明らかになった。

骨髄細胞にEvi9を導入してその効果を調べると、 HL60細胞では、レチノイン酸による顆粒球分化に 際してEvi9の発現がdownregulateされることがわ かった。Evi9の導入によりこの顆粒球分化が顕著 に抑制され、さらに増殖能をえ進させることも明 らかになった。一方、HL60細胞やU937細胞をTPA で刺激してマクロファージへの分化を誘導しても Evi9の発現に変化は見られないが、細胞内におけ る局在の一過性の移動が観察され、現在その意義 について検討している。

これらの結果から、Evi9は転写調節に関与する 蛋白である可能性が考えられ、BCL6や他のPOZ蛋 白、或いはco-repressor等を介して骨髄細胞やBリ ンパ球の転写調節作用に影響を及はして、その分 化・増殖・腫瘍発生に重要な役割を果たしている ことが示唆された。 
ワークショップI $\mathrm{I}$

MALT リンパ腫における MALT1 遺 伝子異常の解析

瀬戸 加大, 米積 昌克

愛知県がんセンター研究所・遺伝子医療 研究部

我々は粘膜関連リンパ組織(MALT)リ ンパ腫に高頻度に認められる染色体転座 $\mathrm{t}(11 ; 18)(\mathrm{q} 21 ; \mathrm{q} 21)$ を解析し、染色体 18 番 バンド q21 領域の責任遺伝子 MALT1 見出した。解析の結果、 $\mathrm{t}(11 ; 18)(\mathrm{q} 21$; q21)転座の本体は、11q21 領域に位置す る API2 (APoptosis Inhibitor protein 2) 遺伝子と MALT1 が API2-MALT1 融合 遺伝子を形成することであることを見出 し報告した。

API2 は N 端側に 3 つの BIR

(Baculovirus inhibitor of apoptosis repeat)ドメインをもち、その C 端側に

CARD (caspase recruitment domain) と RING ドメインを有する 604 アミノ酸か らなる蛋白であり、機能的には TNF receptor II と complex 形成し、 apoptosis の抑制に働くことが示されてい た。MALT1は813/824アミノ酸よりな り、部分的に CD22、Laminin 5 と相同 性を認めるもののその機能並びに細胞内 局在は不明である。転座の結果、API 2 は BIR の C 端側で切断し、MALT1 と in frame で結合するキメラ mRNA を形成 する。

API2-MALT1 遺伝子異常について、 RT-PCR 法を用いて臨床検体を検討した ところ、MALT リンパ腫の約 $30 \%$ の症例 でキメラ遺伝子を形成していることを見 出した。また、蛋白レベルで検討するた めに、tagのついた発現ベクターを構築 し、Cos 細胞に一過性に発現させること で細胞内局在を検討したところ、API2 は 核と細胞質に局在していたが、API2MALT1 は細胞質に局在しており、キメ ラ蛋白を形成することによる異常の一端 が明らかとなった。現在、API2 及び MALT1 に対する特異抗体を作製しつつ あり、臨床検体を用いた検討を進めつつ ある。

$$
\text { ワークショップ I -4 }
$$

FISH と SKY による B 細胞性リンパ腫の分 子細胞遺伝学的診断

京都府立医科大学 第三内科 赤野由美子，小林 都, 野村憲一, 藤田寧子, 上 田亭司, 中尾光茂, 䏱池重夫, 横田昇平, 西田一弘, 加嶋 敬, 谷脇雅史

[緒言] 細胞遺伝学的な方法は, 造血器腫演の病態 解析に有用である. 最近では, LD-PCR, DNA マ イクロアレイ, バンド特異的プローブを用いた SKY が開発され，ゲノム解析の精度はますます向 上している. 我々は G 染色, FISH, SKY を用いて B 細胞性リンパ腫（B-NHL)198 例について染色体 異常の解析を行った.

[方法と結果] FISH とSKY は既報の如く行った. 免 疫グロブリン $\mathrm{H}$ 鎖遺伝子 $(\mathrm{IgH})$ 転座陽性 81 例，陰 性 117 例. 陽性例では, 間期核 FISH によって 65 例(80\%)で転座相手遺伝子が同定できた（BCL2 27 例, BCL617 例, BCL1 12 例, C-MYC 7例, PAX5 2 例). 5 例で 2 種類の $\operatorname{IgH}$ 転座の関与を認め, 臨床 が急激であった．また, $\mathrm{t}(14 ; 18)$ から $\mathrm{t}(9 ; 14 ; 18)$ へ核 型進展した治療抵抗性のろ胞性リンパ腫を経験し, 病勢との関与が示唆された.

IgH 転座陰性の 40 例では，DC-FISH を用いて 5 例で $(11 ; 18)$ を検出した，陽性例はすべて MALTリ ンパ腫で, 初発部位は肺 3 例, 胃 1 例, 眼瞼結膜 1 例であった.

一方.SKYでは 5 6個の分裂像を解析した. G 染色法の核型の修正と確認に有用であり, $\operatorname{add}(3)(q 25), \operatorname{add}(6)(q 11), \operatorname{add}(7)(q 22) な と ゙ の$ 転座相 手も同定できた. 更に, 切断点が同一であっても, 転座相手の異なる非クローン性の異常が見出され たり, 複数の染色体が再構成に関与するマーカー 染色体も稀でなかった.

[考察] SKY では起源不明の染色体転座断片を容易 に同定できるが, 非常に小さいセグメントやテロ メア近傍の転座を検出するのは困難である。これ に対して DC-FISH は微細な転座や DNA レベルで の切断点の解析，間期核診断に有用である. G 染 色，FISH，SKYを組み合わせることによって新し い知見が期待できる. 
ワークショップ I -5

免疫グロブリン遺伝子重鎖可变領域 (VH遺伝子)のsomatic mutation, intraclonal microheterogeneityからみたびまん性大細胞型 B細胞リンパ腫の組織発生と細胞特性

中村直哉,久世哲郎, 橋本優子, 原洋子, 北条洋, 阿部正文

福島県立医科大学医学部第 1 病理

【目的】de novol発生したびまん性大細胞型 B細胞リンパ腫(DLBCL) についてVH遺伝子の somatic mutation(SM) の頻度と分布, および intraclonal microheterogeneity(IM)の頻度を解 析し, 組織発生と細胞特性を検討した。

【症例と方法】SM解析症例は64例でCD5の 発現からCD5+DLBCL10例とCD5-DLBCL54 例にわけ,さらにCD5-DLBCLは節性36例と節 外性18例にわけて検討した。SMの頻度は[最 も homologyの高いgermlineからの変異数/解析 した塩基数](\%), IMの頻度は[germlineからの変 異が認められる塩基の数/解析した総塩基数( 塩基数 $\times$ クローン数 $)](\%) と し て$ 求めた。また CD5+慢性リンパ性白血病(B-CLL)やMALT型 リンパ腫, 濾胞性リンパ腫と比較検討も行っ た。

【結果】CD5+DLBCLではSMの頻度および平 均はそれぞれ0.7\%-12.9\%, 6.2\%で, IM(4例) は 0-0.068\%, 平均 $0.034 \%$ であった。節性CD5DLBCLではSMの頻度および平均は0-25.7\%， $10.7 \%$ でIM(9例)は0-0.204\% 平均 $0.085 \%$ で あった。節外性CD5-DLBCLではSMの頻度お よび平均は5.6-25.9\%, 13.5\%でIM(6例)は 0.204-0.408\% 平均 $0.296 \%$ であった。

【考察】CD5+DLBCLはSMの頻度が低い症例 と高い症例からなる二峰性の分布を示したが CD5-DLBCLは節性, 節外性のいずれも約6$10 \%$ にピークを有する分布を示し，CD5+ DLBCLとは異なった。さらにCD5 ${ }^{+}$DLBCLの IMはSMの頻度に関わらず低值でCD5+B-CLL と類似性を認めた[(SM)11例:0-15.0\%平均 5.5\% (IM)3例:0.098\%]。CD5+DLBCLは胚中心 (GC)を経由するB2細胞とは異なりB1細胞に 由来すると考えられる。節性CD5-DLBCLと 節外性CD5-DLBCLを比較するとSMとIMのい ずれも節外性CD5-DLBCLで有意に高かっ た。CD5-DLBCLはGC細胞もしくはpost-GC 細胞(memory細胞)に由来するとされるが節外 性CD5-DLBCLではmutationのactivityを持続し リンパ腫の発生後もSMが付加されている可能 性があり, 節性CD5-D L B C Lとは異なる細 胞特性を示した。
ワークショップ I -6

CD30過剩発現によるホジキン細胞 の構成的NF-kB活性化機構

堀江良一 ${ }^{1 、 4}$ 、森下保幸 ${ }^{1}$ 、伊藤金次 ${ }^{1 、 3}$ 、石 田尚臣 ${ }^{1}$ 、鐘ガ江裕美 ${ }^{2}$ 、東原正明 ${ }^{4}$ 、斉藤 泉 $^{2}$ 、渡邊俊樹 ${ }^{1}$

東大医科研 ${ }^{1}$ 癌 - 細胞増殖部門人癌病因遺伝 子分野、 ${ }^{2}$ 遺伝子解析施設、 ${ }^{3}$ 東邦大学医学部 病理学、 ${ }^{4}$ 北里大学医学部第 4 内科

ホジキンリンパ腫は少数の腫瘍細胞 $=$ Hodgkin/Reed-Sternberg細胞(H-RS細胞)が多数 の多彩な反応性細胞内に散在する特徵的な組 織像を示す。これはH-RS 細胞の産生する 種々のサイトカインの作用によると考えられ ている。一方、CD30の過剩発現はH-RS細胞 の古くから知られた特徽の一つであり、最 近、NF-KBの構成的活性化もその特徵である ことが報告された。我々は、CD30が細胞質 内領域に結合するアダプタータンパク質 TRAF2, TRAF5を介してIKKを活性化しIKBの リン酸化によってNF- $\mathrm{kB}$ を活性化すること示 した。以上の背景から、我々は、H-RS細胞 における構成的NF- $\mathrm{kB}$ 活性化の分子機構を明 らかにする事を目指した。その結果、CD30 はリガンドとの結合無しに、過剩発現のみで 細胞質内領域を介した self-associationによっ てNF-אBを活性化しうること、過剩発現細胞 株及びH-RS細胞株ではTRAFタンパク質が CD30とcolocalizeすること、これらの細胞に 細胞質内領域を欠損したCD30あるいは TRAF2やTRAF5のdominant negative体を強制 発現させるとNF-KBの活性化が阻害されるこ とを明らかにした。以上の結果はH-RS細胞 に過剩発現するCD30が構成的にNF-кB活性 化シグナルを伝達することを示す。更に、 我々は、H-RS細胞がアデノウイルスベクタ 一に高感受性であり、これを用いてIKB $\alpha$ の dominant negative formを導入するとH-RS細胞 にアポトーシスを誘導出来ることを示した。 以上の結果は、H-RS細胞の増殖とサイトカ イン産生の基礎となるNF-KB活性化の分子機 構を示すとともに、それに基づいた細胞特異 的かつ分子標的特異的な遺伝子治療の可能性 を示すものである。 
ワークショップ I -7

ヒトヘルペスウイルス 8 型 (HHV-8)の感染病理

片野晴隆

国立感染症研究所感染病理部

【目的】ヒトヘルペスウイルス 8 型 (human herpesvirus 8, HHV-8, Kaposi's sarcoma-associated herpesvirus, KSHV)はカポジ肉腫 (KS)、原発性体 液性リンパ腫 (PEL)、多巣性キャッスルマン病 (MCD)に PCR で高頻度に検出される。これらの 疾患における HHV-8 の関わりをウイルスタンパ クの発現、血清学的解析などにより検索した。

【材料と方法】 HHV-8 がコードする K2, および ORF26, K8, K8.1, K10, K11, ORF59, ORF65, ORF73 タンパクに対するウサギポリクローナル抗体を作 製した。抗体の特異性は HHV-8 感染細胞 TY-1 を用いた蛍光免疫染色、およびウエスタンブロッ ティングで確認した。また、血清中の抗 HHV-8 抗体を検出する ELISAを開発した。

【結果】phorbol ester で刺激した PEL 細胞株を用 いたウエスタンブロッティングの結果では K2, および ORF26, K8, K8.1, K10, K11, ORF59, ORF65 タンパクは增殖感染関連タンパク、ORF73 タン パクは潜伏感染関連タンパクであることが示唆さ れた。PEL では ORF73 の高発現が見られ、また、 KS の免疫組織染色では、ほとんど全ての紡鏵形 腫瘍細胞の核内に ORF73 タンパクが発現してい ることが明らかになった。 MCD ではリンパ濾胞 暗殼内の多くの細胞が増殖感染関連タンパクを発 現しており、PELやKS とは異なるウイルスタン パク発現パターンを示していることが明らかにな つた。一方、血清学的解析では KS の全ての患者 血清中に抗 HHV-8 抗体が検出されたものの、 MCD では陰性者が多かった。

【考察】これらのデータは HHV-8 が KS、PEL の病因に重要な役割を果たしていること、 $\mathrm{MCD}$ では KS における役割とは異なる作用をしている ことを示唆しているものと考えられる。

$$
\text { ワークショップII-1 }
$$

\section{NK 細胞腫瘍における癌抑制遺伝子}

$p 15, p 16, R b, p 53$ 恰討

坂尻さくら、川又紀彦、押味和夫

\section{順天堂大学 血液内科}

【目的】p15，p16，Rb，p53は癌抑制遗 伝子として知られている。今回我々はNK 細 胞腫瘍におけるp15，p16，Rb，p53遉伝 子の変異について検討したので報告する.

【方法】 myeloid/NK-cell precursor a cute leukemia 3例, blastic NK-cell lymphoma/leukemia 4例, nasal and nasaI type NK-cell lymphoma 4例, aggressive NK-cell leukemia/lymphoma 4例, chronic NK lymphocytosis 13 例, NK細胞 株4例の計32検体について検討した。p15, p16, p16E1 $\beta, R b, p 53$ deletion/ rearrangementはSouthern法により, 検討 した. p53はエクンン5-8をPCR-SSCP法 を用いて解析した。

【結果】blastic NK-cell lymphoma/leukemiaの2例，nasal and nasal-type NK cell lymphomaの3例でp15, p16, p16E1 B のhomozygous deletionを認めた。Rb のdeletion/rearrangementは認めなかっ た。 p53はSouthern法ではいずれの疾患で も異常を認めなかったが、エクンン5-8に ついてはPCR-SSCP法で現在解析中である。

【考察】NK 細胞腫瘍でp 15，p16の異常が 高率に認められたことからこれらの遺伝子異 常が癌化に関与している可能性がある。 
ワークショップII-2

舅腔 NK/ 細胞リンパ腫の病 理、疫学的検討

大澤政应、青笹克之*

市立池田病院病理。*大阪大学医学部 病理病態

臨床的に進行性鼻壊疽(LMG)の病態 を示す疾患には、組織学的にWegener 肉芽腫症。Polymorphic reticulosis (PR)、通常型のリンパ腫 $(\mathrm{ML})$ が含ま れる。PR は Natural killer(NK)細胞 マーカーの CD56 陽性であることが 報告され現在では NK/T 細胞性リン パ腫とされている。一方 P Rの報告は 本邦を中心とした東アジアからであり。 欧米からは少ない。われわれは PR と MLの発症頻度は本邦は英国に比し約 3 倍の高頻度であること、また、PR の発症瀕度は上海と本邦は同程度であ るが、韓国は 5 倍の高頖度であるこ とを報告した。近年、PR の発症頻度 が本邦や韓国で低下している印象があ るため。PR の発症頻度の経時的変化 を検討した。

【方法および結果】1967.96 年に本邦 59 大学にて診断治療された LMG 症 例、韓国延世大学にて 1977.96 年に 診断治療された LMG 症例の組織学的 再検討を行ない PR の外来新患者数 1 0万人あたりの頻度の変化を 1989 年 前と以降で比較した。PR は本邦では 7 から 6 とほとんど変化無かったが韓 国では40から20へと減少していた。

【考察】Epstein.Barr virus の陽性 率には違いが無いことから韓国の発症 率の低下には EBV 意外の要因が関与 している可能性が考えられた。
ワークショップII-3

Peripheral T-NK-Cell Lymphoma Involving the Nasal Region. Comparison of Indonesian and Japanese Cases 中峯寛和，巽 英二*，田村真司**，三家登喜夫， AN Kumiawan***, Evlina Susanna***

和歌山医大臨床検査医学，*神戸大医学部国際交流セン タ一，**和歌山医大耳鼻咽㮢科，*** Dept Anat Pathol, Fac Med, Univ Indonesia

[Background] Peripheral T-NK-cell lymphomas involving the nasal region, formerly referred to as angiocentric immunoproliferative lesions, are known to be far more prevalent in Asian and Latin American than Western countries. Such uneven geographic distribution of patients with a given disease generally indicates that either genetic or environmental factors, or both, may be responsible for its etiology and/or pathogenesis. The purpose of this study is to compare clinicopathologic features of such patients in districts of Indonesia and Japan [Methods] Cases were collected from the two institutions [Wakayama (Jpn) and Jakarta (Ind)] with the following criteria; non-lymphoblastic lymphoma, non-B-cell phenotype, and major involvement in the nasal region. Histologic, immunophenotypic, and in situ hybridization studies were performed. Clinical information was available, so far, in Jpn cases.

[Results and comments] Eleven Jpn cases and 12 Ind cases which fullfiled the above criteria were collected. Jpn and Ind patients ranged in age from 31 to 82 (with a median of 63) yrs and from 22 to 54 (with a median of 37.5 ) yrs, and a male to female ratio was 7 to 4 and 11 to 1 , respectively. Histologically, all of the cases except for one Jpn cases were characterized to be either grade 2 or 3 . Angiocentric proliferation and necrosis were more prominent in Ind cases. Phenotypically, proliferating cells in the majority of cases in both groups were positive for CD45, CD3 $8, C D 45 R O, C D 43$, and TIA-1. CD56 was positive in 3/11 Jpn cases and 7/12 Ind cases, respectively. All, but one Jpn, cases were negative for $\mathrm{CD} 4$, but $\mathrm{CD} 8$ was positive in $3 / 10 \mathrm{Jpn}$ cases and 5/9 Ind cases. EBER or LMP-1 was positive in 7/10 or $1 / 11$ Jpn cases, and 11/11 or $4 / 11$ ind cases. Three of nine Jpn patients, who showed elevated serum $L D H$ level and no response to cytotoxic therapy, died of the disease within 21 months.

There were no distinctive differences in hematopathologic features between the two groups of cases. Analysis of climical data of Ind patients is in progress. 
ワークショップII-4

皮下組織を侵す NK および T 細胞リンパ腫 の解析: 鼻腔 $\mathrm{NK} / \mathrm{T}$ 細胞リンパ腫との比輬検討

鈴宮淳司、“大島孝一、田村和夫、"菊池昌弘

福岡大学一内科。”一病理

【目的】新WHO 分類では“いわゆるNK細胞リンパ腫” は鼻および鼻型 NK/T細胞リンパ腫として分類されて いる。しかし、皮下組織を侵す $N K / T$ 細胞リンパ腫は 皮下脂肪織炎様 $\mathrm{T}$ 細胞リンパ腫 (SCPTCL) との異同 の問題がある。皮下組織を侵すNKおよびT細胞リン パ腫を多方面より解析し、鼻 NK/T 細胞リンパ腫と比 較検討した。

【対象·方法】凍結組織の検討可能な原発性の皮下 組織を侵す非 B 細胞リンパ腫(皮膚リンパ腫と略) 16 例 (男性 4 例;女性 12 例、年齢中央値 55 歳)、鼻腔原 発非 B 細胞リンパ腫(鼻リンパ腫と略) 15 例(男性 6 例;女性 9 例、年齢中央值 46 歳)。細胞形質の検討は 凍結およびパラフイン切片に各種抗体を用いた免疫 染色を施行。細胞系統の検討はサザン法を行い、 EBV は ISH 法、PCR 法、サザン法で検討した。

【結果】I 皮膚リンパ腫: TCR 遺伝子再構成と CD56 発現より 3 型に分けられる。(1)NK細胞性 (CD56 陽性、 TCR 胚芽型) 6 例 $(37.5 \%)$ 。組織型は pleomorphic type(PL) 5 例。centroblastoid type (CB) 1 例。CD5。 TCR $\beta$ は陰性。TIA-1 は 1 例を除き陽性。CB 1 例を 除く全例に EBV 感染を認める。(2)CD56 陽性 T 細胞 性 (CD56 陽性、TCR 再構成) 6 例 (37.5\%)。組織型は $\mathrm{PL} 2$ 例。CB 2 例、anaplastic large cell type 2 例。CD5 は $3 / 4(75 \%)$ 陽性、TCR $\beta$ 4/6(66.7\%)陽性。TIA-1 は 1 例を除き陽性。 1 例以外は EBV 感染を認めず。(3) CD56 陰性 T 細胞性 (CD56 陰性 TCR 再構成) 4 例 $(25 \%)$ 。組織型は PL 3 例、CB 1 例。CD5、TCR $\beta$ 、 TIA-1 は陽性。EBV 感染を認める 1 例以外は SPTCL に相当する。鼻リンパ腫: CD56 陰性 T 細胞リンパ 腫は認めず。NK 細胞性 13 例 (86.7\%)。組織型はPL 11 例、CB 1 例、 lymphoblastic type(LB) 1 例。LB 1 例 を除く全例に EBV 感染を認める。(2)CD56 陽性 T 細 胞性 2 例 (13.3\%)。組織型はPL および LB 各1例。 $P L 1$ 例にEBV 感染を認める。

【結語】皮下組織を侵すリンパ腫はいくつかの種類が あり、組織型だけではその診断はできず、細胞形質 のみならず TCR 遺伝子解析が必要である。CD56 発 現とEBV 感染はSCPTCLと他のリンパ腫の鑑別の一 助となる。鼻 NK/T 細胞リンパ腫の多くは NK 細胞型 である。CD56 陽性T細胞リンパ腫の位置づけは今後 の検討課題である。
ワークショップII-5

小腸の $\mathrm{CD} 56^{+} \mathrm{CD} 8^{+} \mathrm{T}-$ cell lymphoma の 3 例

定平吉都、真鍋俊明

川崎医科大学病理学教室

[目的] 小腸の $\mathrm{CD} 56^{+} \mathrm{CD} 8^{+} \mathrm{T}$-cell lymphoma は日本 からの報告はきわめて稀である。今回、我々が経験 した 3 症例について病理学的特徽を報告する。

[症例] 1990 年から現在までに、当院病理部で診断 した小腸悪性リンパ腫の外科切除例 10 例のうち 3 例に CD56 ${ }^{+} \mathrm{CD} 8+$ のものが見出された。症例 1 は 45 歳女性。症例 2 は 43 歳女性。症例 3 は 75 歳男性。 これらはいずれも多発漬湯を形成し、小腸穿孔にて 緊急手術が施行されていた。いずれにも腸疾患の 既往はなかったが、症例1では肺にも病変が確認さ れている。組織学的には、腫瘍細胞はいずれも中 型で明るい細胞質を有していた。一部で lymphoepithelial lesion もみられたが, 潥漫性壁全層 性に浸潤增殖する特徵がみられた。パラフィン切片 免疫組織化学および in situ hybridization では, いず れも CD1 $\mathrm{a}^{-} \mathrm{CD} 3 \varepsilon^{+} \mathrm{CD} 8^{+} \mathrm{CD} 20^{-} \mathrm{CD} 30^{-} \mathrm{CD} 45 \mathrm{RO}^{+} \mathrm{CD} 56^{+}$ CD57-TIA-1 ${ }^{+}$Granzyme ${ }^{+}$EBER-1'の形質を示した。 症例 1 はフローサイトメトリーにて、症例2は㾢結切 片免疫組織化学で s-CD3+CD4が確認され、電顕的 には type I と type II の細胞障害性顆粒が cluster 状に見られた。また、症例 1 では Southern blot で TCR C $\beta 1$, Jyの再構成, JSの欠落を認めた。症例 2, 3 はパラフイン切片を用いたPCR 法にてTCR $\gamma$ 鎖の 再構成を認めた。経過中に白血化は見られていな い。

[考察] 小腸の $\mathrm{CD} 56^{+} \mathrm{CD} 8^{+}$lymphoma は、いわゆる NK-like T-cell lymphoma の範疇に入り、活性化した 腸上皮内 Tリンパ球 (intraepithelial T lymphocyte) が EB ウイルスの関与なく腫瘍化したものと推定され る。今後、小腸の T-cell lymphoma は CD56 を含め て詳細に検討する必要があろう。 
ワークショップII-6

Peripheral T/NK cell lymphoma

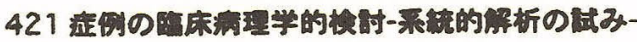

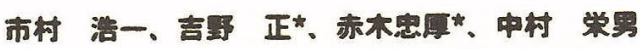

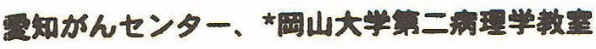

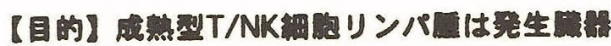

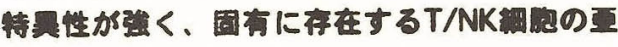

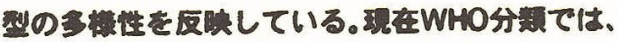

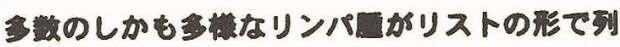
纪される。しかし相互の湖柔化がなされたもの

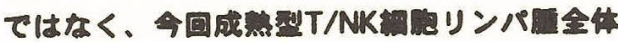

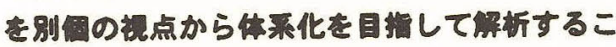
とを站みた。

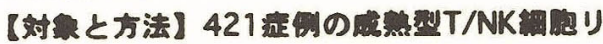

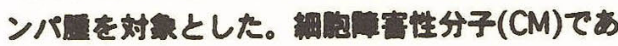
るTIA-1/Granzyme B. NK cell markerとして CD56/57 、 memory $T$ cell marker $て ゙ る$ CD45RO.CD4/8、EBVを端需した。これら性

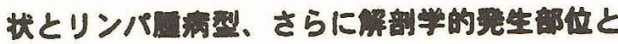

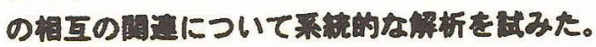

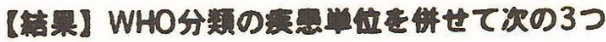
の畺群を設定した。

1. Effector memory T/NK cell lymphoma ; CM

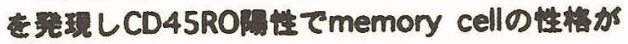

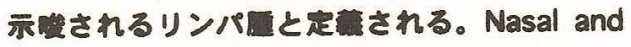
Nasal type NK/T cell lymphomaとT/NK cell lymphoma of unspecified (WHO) と分䆓

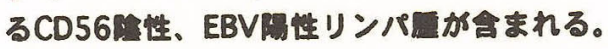

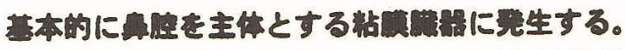
2.Effector naive T cell lymphoma ; CMを発致 し.CD45ROM性となる比まの佂いリンパ:

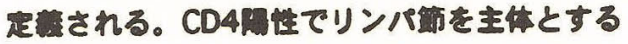

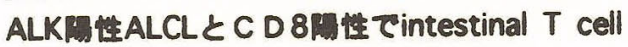

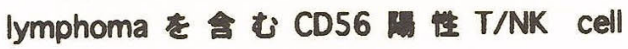
lymphomaがこの謙に念むれる。

3. Central memory T cell Iymphoma; CMF性 でむるか、CD45RON性でありmemory cellの

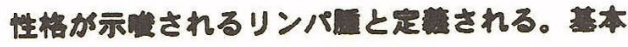

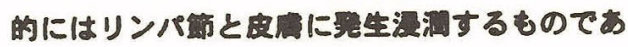
り、AILD, ATLL, MFが誉げられる。
ワークショップII-7

Cytotoxic $T$ ccll lymphoma 5 例の臨床 病理学则解析

向井隄美、米野环堿、長谷川雄一、小岛 寛、

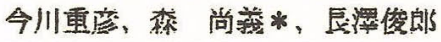

筑波大学血淮内科、*名古层大学第一病理

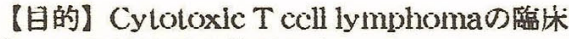
的、病理的特徽を㭘討した。

【力法】Cylotoxic T cell lymphoma 刘象とし、濫床像、HE染色像、免疫染色所 見、予後を检討した。

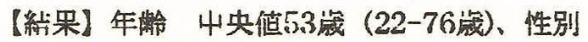
$M: F=2: 3$ 、初発聇状 発熱 3 例、表在リンバ節

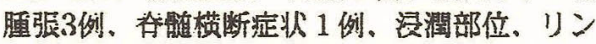
分節 5 例、節外病変 1 例（学鹤 3 例、皮庵 2

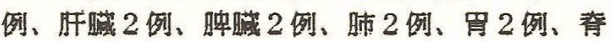

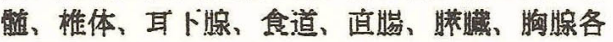
1例）：初発時および再発時にDICを併発した ものを2例、吾しい蔵器障害（肝、背、瞙）を 吕したものを 3 例衿めた。リンパ節生検および

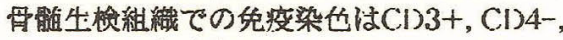
CD8+の細胞障客型定示した。 verfurin, grantyme $\mathrm{B}$, TIA-1( $\mathrm{J}$-cell intercellular antigen-1)が全例で陽性であった。組織学的に はREAI分類でperipheral T-cell tymphoma, unspecified 4 例, angiocentric lymphoma 1 例であった。

予後多剂作用化学癔法に上り 5 例中 3 例は一 度CRとなったが、この内2例は早期に再発し た。1例は大量化学療法および自家骨䯘移俏後 早期に感染症で死亡した。その他1例は治療抵 抗性で発症加ら2ヶ月で死しし、残り1例はPR

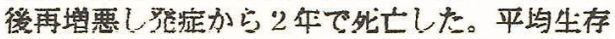
期問は15ケ月（2ケ月-2年9ケ月）であった。

【考察】Cytotoxic 'T" cell tymphomaは発症時

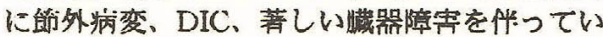
ることが多く、治洗抵抗性で予後不良とされて いる。化学療法でCRを獾得しても、早期に席 登してしまうため、若年考においては祅脚時よ り造血幹細施移植を含む治療戦略をたてていく ことが重要と考えられた。 
ワークショップII-8

進行期・鼻 $\mathrm{NKJT}$ 細胞性リンパ腫に対する 大量化学療法に基づく治療戦略

鏡味良豊 $^{1} \cdot$ 近藤英牛 ${ }^{1} \cdot$ 真栄田聡子 $^{1} \cdot$ 尾山卓 ${ }^{1} \cdot$

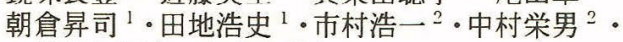
小椋美知則 ${ }^{1}$ ・森島泰雄 ${ }^{1}$

愛知県がんセンター病院・1 血液化療、²遺伝子 病理診断

【目的】 nasal および nasal type NK/T cell lymphoma は、病期の進行した症例では CHOP 療 法の奏功する頻度は低く、絶対的に予後不良であ る。このため治癒をめざした治療として、CHOP 療法とは異なる治療戦略を考慮するべきであるが、 現在まで、まだ有効な治療法はない。今回我々は、 進行期・鼻 NK/T 細胞性リンパ腫に対し、導入化 学療法に自家末梢血幹細胞移植を組み込んだ治療 を行ったので報告する。

【症例】症例 1 は 54 歳男性、鼻腔および顔面皮 膚に発症。骨髄穿刺にて、EBV 陽性の CD56 陽 性細胞をわずかに認めるため、病期は、IVA で あった。治療は、Gianni らの high dose sequential 療法 (CHOP x 2, 大量 CPM, 大量 MTX,大量 VP-16)を行い、2 コースの CHOP 療 法後には、骨䯣の病変が消失した。CPM 投与後 に末梢血幹細胞を採取し、全化療終了時は完全寛 解之考えられた。その後、前処置をMito + L-PAM として未梢血幹細胞移植を施行したが、Day 60 ごろから発熱と汎血球減少および肝脾腫が出現し、 骨䯣での再発が確認され、死亡された。症例 2 は 45 歳女性、鼻腔および前胸部皮䖉に発症。骨 䯣穿刺にて、EBV 陽性の CD56 陽性細胞を認め、 病期は、IVA であった。2 コースの CHOP 療法 後に部分寛解となり、その後 CHASE 療法(大量 $\mathrm{AraC}+\mathrm{CPM}+\mathrm{VP}-16+$ Dexa)に変更して、末 梢血幹細胞を採取し CD34 positive selection を 行った。前処置をLEED(CPM + VP16 + L-PAM) にて純化末梢血幹細胞移植を施行したが、移植後 2 ケ月で原発皮膚部に再発が確認された。再度、 CHASE 療法を行うも部分寛解であり、大量 MTX も不変であった。再度、前処置を MCVC( MCNU + CBDCA + VP16 + CPM )とした純化末梢血幹 細胞移植を施行したところ完全寛解となり、原発 部に放射線照射を追加した。患者は、移植後 5 ケ月現在完全寛解中である。

【結論と考察】進行期・鼻および鼻型 NK/T 細胞 性リンパ腫の化学療法では、CHOP like regimen での治療に限界があり、他の化学療法剂の併用や 治療強度の增強が必要であると考えられる。 Upfront での大量化学療法は、症例数や観察期 間の問題から現時点での評価は困難であるが、有 効である可能性がある。しかしながら、腫瘍の骨 髄浸潤の診断は慎重を要し、腫瘍浸潤が疑われる 際は、採取移植片中からの purging を考慮すべき であると思われる。 